\title{
Insurer Performance and Intermediary Remuneration: The Impact of Abandonment of Contingent Commissions
}

\author{
Yu-Luen $\mathrm{Ma}^{\mathrm{a}}$, Nat Pope ${ }^{\mathrm{a}}$ and Xiaoying Xie \\ ${ }^{a}$ Katie School of Insurance and Financial Services, Illinois State University, Campus Box 5490, Normal, IL \\ 61790-5490, U.S.A. \\ ${ }^{\mathrm{b}}$ Department of Finance, California State University, 800 N. State College Blvd., Fullerton, CA 92831-3599, \\ U.S.A.
}

The advent of the 2004 Spitzer investigation subjected the use of contingent commissions to significant scrutiny in the public media. This research uses the Spitzer investigation as a point of differentiation and assesses the relationship shared by the abandonment of contingent commissions and insurer performance across the pre- and post-2004 periods. Our research defines insurer performance using efficiency measures derived through data envelopment analysis. We employ a difference-in-difference methodology to control for extraneous environmental factors across the time period under consideration, 1993-2008. Our results suggest that the decision to abandon the use of contingent commissions after 2004 is associated with decreases in insurer performance. We attribute that reduction in performance to insurers' abandonment of otherwise performance-maximising remuneration strategies in an attempt to distance themselves from any potential negative associations with the use of contingent commissions.

The Geneva Papers (2014) 39, 373-388. doi:10.1057/gpp.2013.12

Keywords: contingent commission; insurer efficiency; DEA

Article submitted 25 January 2012; accepted 7 March 2013; published online 5 June 2013

\section{Introduction}

Commission-based remuneration strategies are commonly employed in the insurance industry as a means of mitigating the inherent agency dilemma. ${ }^{1}$ Contingent commissions represent a further refinement of those strategies by incentivising insurance intermediaries to pursue specific production goals valued by insurers. ${ }^{2}$ Typical goals that trigger contingent commission payments include the meeting of specific retention rates, premium production goals, and/or profitability measures on portfolios of business. While effective in its ability to align the interests of intermediaries and

\footnotetext{
${ }^{1}$ The agency dilemma (also known as the principal-agent problem) concerns the potential lack of alignment of the goals and interest of one party (the agent), to act on behalf of another (the principal).

${ }^{2}$ For our purposes in this paper, our reference to insurance "intermediaries" focuses solely on independent intermediaries, that is independent agents and brokers. Given the tethered relationship exclusive agents share with a single insurer, the use of contingent commissions as a form of remuneration is largely rendered moot.
} 
insurers, the practice simultaneously establishes a potential conflict of interest with respect to the intermediary's duties to the customer. ${ }^{3}$ Allegations of steering and bid rigging in the 2004 Spitzer investigation brought the practice to the forefront and subjected it to intense public scrutiny. ${ }^{4}$ While similar complaints subsequently issued in other states only implicated a handful of intermediaries and insurers, the allegations and their negative associations reverberated throughout the industry. ${ }^{5}$ Eventually the four largest insurance brokers and a handful of major insurers agreed to arrangements that included significant financial settlements in addition to bans on the payment/ acceptance of contingent commissions as a form of remuneration. ${ }^{6}$ The ban on the collection of contingent commissions was rescinded as of January 2010, and a few affected brokers voluntarily continued to eschew the acceptance of contingents to varying degrees, citing the importance of the removal of any hint of improprieties. ${ }^{7}$

Irrespective of any potential negative associations with the complaints issued in 2004, the percentage of insurers that use contingent commissions have been relatively stable across the 1993-2008 period. In any given year, only about half of U.S. propertycasualty insurers use contingent commissions and of those insurers, about 5-10 per cent of them abandon the practice in the subsequent year. Prior to 2004, the decision to abandon the practice would likely be part of the broader strategic plans of an insurer to enhance its performance. However, given the significant value insurers place on their reputations as fiduciary entities, ${ }^{8}$ the industry may have been influenced by a desire to distance themselves for any possible negative associations with the practice. ${ }^{9,10}$

This study investigates the relationship between an insurer's decision to abandon contingent commission practices and the impact on firm performance. We define performance in terms of efficiency measures and employ a comparative approach by segmenting our data into two pools, pre- and post-2004. We calculate the efficiency changes of insurers that decided to abandon the use of contingent commissions. Using difference-in-difference quasi-experimental methodology that controls for firm and environmental factors, we find that insurers that abandon contingent commissions prior to 2004 experienced efficiency gains for their decisions (as would be anticipated) while the abandonment of contingent commissions during the post-2004 period is not

${ }^{3}$ Cummins and Doherty (2006).

${ }^{4}$ Within the insurance context, "steering" is the practice of an intermediary guiding a client to a given insurer based on motives other than the client's best interest. "Bid rigging" is one method by which an intermediary might endeavour to "steer" a client to a predetermined insurer. It is a scheme in which insurers and intermediaries collude to generate artificially high bids presented to a customer while ensuring that a prearranged insurer will win the account given its relatively lower bid.

${ }^{5}$ Fitzpatrick (2006).

${ }^{6}$ See for example, the settlement agreement between Marsh \& McLennan and the State of New York (www.dfs.ny.gov/insurance/dept_inv/oag050130.pdf).

${ }^{7}$ Simpson (2010).

${ }^{8}$ Csiszar and Heidrich (2006).

${ }^{9}$ For example, the Willis Group has gone so far as to publically recognise the conflict of interest inherent in the use of contingent commissions and formally (largely) rejects the acceptance of such commissions (www.willis.com/About_Willis/The_Willis_Way/Our_Policy_On_Contingency/).

10 The investor marketplace positively associates the use of contingent commissions with performanceenhancement strategies (Cheng et al., 2010; Ghosh and Hilliard, 2012). 
associated with the same benefits, a finding we attribute to an insurer's motivation for abandonment for reasons not associated with performance-enhancement.

Our research findings are of significant interest to insurers as they attempt to (re)assess their intermediary remuneration strategies in light of the public debate on the use of contingent commissions, which is a highly sensitive issue to the public and customers. Given their broader interest in the efficiency with which the insurance industry functions, state regulators, legislators and attorneys general's offices will also find the research of interest, as it reveals additional information on the impact of contingent commission usage on insurer operations.

The next section of this paper presents background information and a literature review of related research on contingent commissions. We then present our research methodology, which includes a discussion of data envelopment analysis (DEA), a nonparametric technique we employ in generating our measures of efficiency. The paper concludes with a summary of our results and their associated implications.

\section{Background and literature review}

Contingent commissions are a form of intermediary remuneration that has been a part of the U.S. property-casualty insurance market since the $1950 \mathrm{~s} .{ }^{11}$ They are different from most other forms of commission-based remuneration in the insurance industry in that they are paid retrospectively, typically on an annual basis. While contingent commissions themselves may represent a relatively small value when compared to overall premium volumes, these commissions help shape the character of the book-ofbusiness held by an insurer and, thus, have the ability to significantly impact an insurer's revenue and cost structure. ${ }^{12}$

The use of contingent commissions provides a number of benefits to all parties involved in the insurance transaction. ${ }^{13}$ Also, as noted earlier in the paper, the practice serves to align the goals of insurers and intermediaries, thereby mitigating the agency dilemma. ${ }^{14}$ However, the use of contingent commissions also has the potential to create moral hazard. For example, the bilateral character of these contracts (these agreements include insurers and intermediaries-customers are not party to the contract) could potentially create a conflict of interest on the part of the intermediary in its duty to the customer. Contingent commission agreements create inducements for intermediaries to engage in fraudulent activities such as steering and/or bid rigging. ${ }^{15}$

\footnotetext{
${ }^{11}$ Wade (2005) offers a deeper discussion of the background and history of contingent commission usage in the U.S. insurance marketplace.

${ }^{12}$ As of 2004, contingent commissions represented 1.1 per cent of the total premiums generated by the U.S. property-casualty industry. However, from the perspective of intermediaries such commissions sometimes comprise a significantly larger proportion of their total revenue. In 2004, contingent commissions represented 5.3 per cent (approximately $\$ 19.5$ million) of the total revenue for the 50 largest brokers. For Marsh \& McLennan alone (the largest insurance broker in the world at the time) contingent commissions were 7.3 per cent ( $\$ 423$ million) of its total revenues.

13 Hoyt et al. (2006).

${ }^{14}$ Hartwig (2005); Cummins and Doherty (2006).

15 Schwarcz (2007).
} 
Such activities have typically served as the basis for the complaints issued by the various state attorney general offices.

As noted in the introduction of the paper, only a little over half of the U.S. property-casualty insurers use contingent commissions in any given year. Colquitt et $a l .{ }^{16}$ find that certain insurer characteristics are positively associated with the practice, for example, larger insurers and insurers with lower loss ratios. In addition, insurers that are diversified, both in terms of lines of business and geographically, and those that are more heavily focused on personal lines, tend to be more likely to use contingent commissions.

The relationship contingent commissions share with insurer performance has also been the subject of significant investigation. Regan and Kleffner ${ }^{17}$ examine the relationship between contingent commission usage and insurer underwriting performance during the 2001-2005 period. They find that insurers that have relatively lower loss ratios are more likely to engage in the practice and also find that relatively higher levels of usage are associated with relatively better underwriting results. In contrast, Ma et al. ${ }^{18}$ find that contingent commission usage is not uniformly associated with better firm performance. Using data over the 1993-2008 period, Ma et al. ${ }^{19}$ find a negative relationship between the use of contingent commissions and levels of performance (where performance is defined in terms of both financial and operational efficiency terms). They find that non-users of contingent commissions are more cost and revenue efficient when compared to insurers that use contingent commissions. However, the investigation by Ma et al. ${ }^{20}$ also finds that, among users of contingent commissions, relatively higher levels of use of contingent commissions are associated with similarly higher levels of performance - a finding that would tend to agree with Regan and Kleffner. ${ }^{17}$ In yet another study, $\mathrm{Ju}$ and $\mathrm{Tu}^{21}$ find that the use of contingent commissions is associated with a dampening of the negative effects of the insurance underwriting cycle. One implication of these various findings is that use of contingent commissions is not a guaranteed panacea for improved performance but rather, it is a complex relationship.

\section{Hypotheses and research methodology}

We measure insurer performance using efficiency measures. Specifically, we evaluate whether the abandonment of a contingent commission payment system is associated with changes in insurer cost and revenue efficiencies ( $C E$ and $R E$, respectively) and total factor productivity $(T F P)$. Using the Spitzer investigation as a point of delineation, we perform parallel analyses on insurers that abandoned the contingent commission system on a pre- and post-Spitzer basis. This manner of comparison allows us to draw

\footnotetext{
16 Colquitt et al. (2011).

${ }^{17}$ Regan and Kleffner (2010).

18 Ma et al. (2009).

${ }^{19} \mathrm{Ma}$ et al. (2013).

${ }^{20} \mathrm{Ma}$ et al. (2013).

${ }^{21} \mathrm{Ju}$ and $\mathrm{Tu}$ (2011).
} 
inferences as to possible changes in motivation for the abandonment of contingent commissions after 2004. If insurers can be presumed to pursue performancemaximisation consistently across time and strategically employ agent remuneration in support of that goal, one should expect to find a positive relationship between shifts in those remuneration strategies and positive performance results, ceteris paribus.

Given the significant negative attention contingent commissions received in the media subsequent to the Spitzer investigation, some insurers may choose to abandon the use of contingent commissions as a means of distancing themselves from potentially negative associations with the practice. If the motivations for the abandonment of contingent commissions were for the purpose of preserving one's public image, the abandonment might actually incur a cost - a cost that would likely be reflected in a reduction in performance. Thus, we test the following two hypotheses in our empirical analyses:

Hypothesis 1: Insurers that abandon contingent commissions during the pre-Spitzer period experience performance gains, relative to insurers that continue to use that form of remuneration.

Hypothesis 2: Insurers that abandon the contingent commissions during the postSpitzer period experience performance losses, relative to insurers that continue to use that form of remuneration.

\section{Mathematical programming}

We use DEA, a non-parametric technique, to calculate both CE and RE scores. ${ }^{22}$ The efficiency scores of a firm tell how well a firm performs in minimising costs and maximising revenues relative to "best practice" frontiers formed by the fully efficient firms in the industry. CE measures each firm's performance in minimising costs by choosing input quantities while holding constant the input prices and output quantities. Assuming there are $N$ firms in the industry, and each firm produces $m$ outputs with $k$ inputs, we can calculate firm $j$ 's optimal cost by solving the following linear programming problem:

$$
\begin{gathered}
C^{*}(x, y)=\operatorname{Min}_{\lambda, \mathbf{x}_{\mathbf{j}}^{*}} \sum_{r=1}^{k} w_{r j} x_{r j}^{*} \\
\text { subject to : } \sum_{j=1}^{N} \lambda_{j} y_{i j} \geqslant y_{i j} \quad \forall i=1, \ldots, m \\
\sum_{j=1}^{N} \lambda_{j} x_{r j} \leqslant x_{r j}^{*} \quad \forall r=1, \ldots, k \\
\lambda_{j} \geqslant 0 \quad \forall j=1, \ldots, N,
\end{gathered}
$$

\footnotetext{
22 Cooper et al. (2000).
} 
where $\mathbf{w}=\left(w_{1}, w_{2}, \ldots, w_{k}\right)$ is the input price vector, $\mathbf{y}=\left(y_{1}, y_{2}, \ldots, y_{m}\right)$ is the output quantity vector, and $\mathbf{x}_{\mathbf{j}}{ }^{*}=\left(x_{1 j}{ }^{*}, x_{2 j}{ }^{*}, \ldots, x_{k j}{ }^{*}\right)$ is the optimal input quantity vector that minimises the costs of producing $\mathbf{y}$ with input price $\mathbf{w} . C E$ is defined as:

$$
C E(x, y)=\frac{\sum_{r=1}^{k} w_{r j} x_{r j}^{*}}{\sum_{r=1}^{k} w_{r j} x_{r j}},
$$

where $\mathbf{x}_{\mathbf{j}}=\left(x_{1 j}, x_{2 j}, \ldots, x_{k j}\right)$ is the actual input level of the firm.

$\mathrm{RE}$, on the other hand, is output-oriented. RE measures a firm's performance in maximising revenues by optimising output quantities, while holding output prices and input quantities constant. A firm's optimal output quantity is calculated by solving the following programme:

$$
R^{*}(x, y)=\operatorname{Max}_{\lambda, y_{j}^{*}} \sum_{i=1}^{m} p_{i j} y_{i j}^{*}
$$

$$
\begin{aligned}
\text { subject to }: & \sum_{j=1}^{N} \lambda_{j} y_{i j} \geqslant y_{i j}^{*} \quad \forall i=1, \ldots, m \\
& \sum_{j=1}^{N} \lambda_{j} x_{r j} \leqslant x_{r j} \quad \forall r=1, \ldots, k \\
& \lambda_{j} \geqslant 0 \quad \forall j=1, \ldots, N,
\end{aligned}
$$

where $y_{j}=\left(y_{1 j}, y_{2 j}, \ldots, y_{m j}\right)$ and $y_{j}{ }^{*}=\left(y_{1 j}{ }^{*}, y_{2 j}{ }^{*}, \ldots, y_{m j}{ }^{*}\right)$ represent firm $j$ s actual output quantities and the revenue-maximising output level, respectively, and the $p_{i j}$ represent output prices. A firm's RE is then defined as

$$
R E(x, y)=\frac{\sum_{i=1}^{m} p_{i j} y_{i j}}{\sum_{i=1}^{m} p_{i j} y_{i j}^{*}} .
$$

We use linear programming to solve the minimisation and maximisation problems identified above.

In addition to measuring the changes in firms' cost and RE, we also use the Malmquist index (which is also DEA-based) to measure firms' TFP change. A Malmquist index (TFP change) greater than one implies an improvement in TFP, while an index smaller than one implies a regress in TFP. The Malmquist index has been well discussed in the literature, ${ }^{23}$ and in this research we estimate the $(t-1, t+1)$

${ }^{23}$ See Grosskopf (1993); Fare et al. (1994); Cummins et al. (1999). 
input-oriented Malmquist index for each firm in the U.S. property-casualty industry following the mathematical programming described in Cummins et al. ${ }^{24}$

\section{Outputs and output prices}

We adopt a modified version of the value-added approach in defining insurance outputs. ${ }^{25}$ Insurers provide three major types of services: risk pooling and risk bearing services, real financial services, and financial intermediation services. Following previous studies, proxies are used to measure the outputs of the services provided by insurance companies. We use the present value of losses incurred as a proxy for risk pooling, risk bearing, and real financial services. Because different lines of coverage represent different levels of risks and services, separate estimations are obtained for personal lines short-tail losses, personal lines long-tail losses, commercial lines shorttail losses, and commercial lines long-tail losses. We apply a loss smoothing procedure to the calculation of outputs to correct for the randomness of losses, as in Cummins and Xie. ${ }^{26}$ The quantity of intermediation services is measured by real invested assets, averaging the beginning- and end-of-year value.

The output price for each insurance line is calculated as ${\text { Output } \text { Price }_{i}=}$ $P E_{i}-L L E_{i} / L L E_{i}$, where $P E_{i}$ denotes the real premiums earned of insurance output $i$, and $L L E_{i}$ denotes the real present value of losses and loss adjustment expenses incurred of insurance output $i$. The price of the financial intermediation output is defined as the weighted average of the expected return on stocks and the realised return on interestbearing assets.

\section{Inputs and input prices}

As in prior insurance literature, we consider labour, materials and business services, and equity capital as the inputs for production. ${ }^{27} \mathrm{We}$ split labour into two categories: administrative labour and agent labour. The quantities of inputs are imputed from the dollar value of expenses on each input and their prices.

The price for administrative labour and agent labour inputs are defined as the U.S. Department of Labor (DOL) average weekly wage for employees in insurance companies and the DOL average weekly wage for insurance agents, respectively. The price for materials and business services is calculated by taking the weighted average of price indices for business services from the expense page of Best's Aggregates and Averages. Our measurement of the price of equity capital parallels that of Cummins et $a l^{24}$ We first use the Fama-French three-factor model ${ }^{28}$ to estimate the cost of capital for public insurers in different Best's rating categories, then assign the same costs of capital to private insurers based on their ratings. ${ }^{29}$

\footnotetext{
${ }^{24}$ Cummins et al. (1999).

${ }^{25}$ Berger and Humphrey (1997); Berger et al. (1997); Cummins and Xie (2008); Cummins and Weiss (2011).

${ }^{26}$ Cummins and Xie (2008).

${ }^{27}$ Cummins and Nini (2002); Cummins and Xie (2008); Cummins and Weiss (2011).

${ }^{28}$ Cummins and Phillips (2005).

${ }^{29}$ Robustness checks conducted by previous studies reveal that cost-efficiency scores are robust to alternative cost of capital measures (Cummins et al., 1999; Cummins and Nini, 2002; Cummins and Xie, 2008).
} 
380

\section{Data and model specification}

Our data used in the analyses come from a handful of sources. Most insurance company-specific data, including contingent commissions, are derived from the regulatory annual statement database maintained by the National Association of Insurance Commissioners (NAIC). Supplementary data, such as the distribution systems employed by insurers, is obtained from publications of the A.M. Best Company, an insurance financial rating firm. To calculate input and output prices for the efficiency measures, we also need data from the 2009 Stocks, Bonds, Bills, and Inflation Valuation Edition Yearbook; the U.S. Department of Commerce Bureau of Economic Analysis; and U.S. DOL. Our data covers the time period 1993-2008.

Whether or not a firm decides to abandon the contingent commission system is not reported in any database and thus needs to be imputed. To analyse performance changes in firms that abandon contingent commission prior to Spitzer's investigation, we start with all affiliated and unaffiliated companies reported in the NAIC Database, then select firms with continuous data available during 1993-2004. Among these firms, we identify firms that use contingent commissions throughout 1993-2004; firms never using contingent commissions during this period, and firms with mixed usage. We select a study sample of abandoning firms from the mixed usage category by requiring that a firm pays contingent commission at $t-1$, while ending the practice in both year $t$ and year $t+1 .^{30}$ Hence, possible action years are from 1994 to 2003 . We denote the action year as year $t$; performance changes between $t-1$ and $t+1$ are calculated for each selected firm. We use as our control sample firms that use and never abandon contingent commission practices throughout 1993-2004. We assign pseudo-action years to these control firms, and also calculate their performance changes between $t-1$ and $t+1$. The study sample and control sample for the postSpitzer period are selected similarly; we select firms from a sample of firms with continuous data during 2003-2008, with action years being year 2004-2007, when the media had the most influential impact on firms' decisions on contingent commission strategies.

The regression sample for the pre-Spitzer period includes a total of 3,390 observations, among which 466 observations abandoned the usage of contingent commission sometime during 1994 and 2003. For the post-Spitzer period, the sample includes a total of 2,188 observations, where 233 firms stopped using contingent commissions during the 2004-2007 period. The sample size is reduced in the efficiency change statistics and regressions because we apply more rigorous data screening criteria when estimating firm efficiency, which results in missing values of efficiency for some observations. ${ }^{31}$

${ }^{30}$ While it is possible that a firm reports zero contingent commission payments in any given year due to lack of qualifying business, it is unlikely that this pattern persists for two consecutive years.

${ }^{31}$ For efficiency estimation, we start with all affiliated and unaffiliated companies reported in the NAIC database, then eliminate firms whose financial data do not satisfy the data screening criteria for efficiency estimation (see Cummins and Xie, 2008), such as firms with zero or negative net worth, premiums, or inputs, firms with unrealistic premiums-to-surplus ratios, etc. 
To control for the potential environmental differences across the pre- and postSpitzer periods, we use difference-in-differences regression estimation techniques. Using the non-abandoning insurers as a control group for comparative purposes, the methodology allows us to isolate the relative changes in performance by insurers that actually abandon the practice during the post-Spitzer period. ${ }^{32}$ The difference-indifference method removes biases in performance changes from pre- to post-Spitzer periods due to economic or other market factors that affect all insurers. It also removes biases from comparing changes in performance between abandoners and insurers that do not change their intermediary remuneration methods during the postSpitzer period that are not readily attributable to the Spitzer investigation.

Our multivariate regression model is specified as follows:

$$
\Delta P_{i, t}=\alpha+\beta * C_{i, t}+\gamma * \lambda_{t}+\delta * \lambda_{t} * C_{i, t}+\sum \gamma * Z_{i, t}+\varepsilon_{i, t}
$$

where $i$ represents insurer $i, t$ represents year $t$ and $\varepsilon_{i t}$ is the random error term of the model. The dependent variable $\Delta P_{i, t}$ is measured by the changes in firm performance from year $t-1$ to year $t+1$, with year $t$ as the abandonment year. There are three different measures of $\Delta P_{i, t}$. They are: $C E_{t+1} / C E_{t-1}, R E_{t+1} / R E_{t-1}$ and $T F P_{(t-1, t+1)}$ where $C E, R E$, and $T F P$ represent $C E, R E$, and $T F P$, respectively. $C$ is dummy variable indicating whether a firm abandons the contingent commission system in year $t$. The value of $C$ is set to 1 if a firm abandons the contingent commission system in year $t$ and 0 otherwise. The coefficient $\beta$ captures the changes in firm performance experienced by abandoners when comparing to keepers during pre-Spitzer period. $\lambda$ is a dummy variable for post-Spitzer period. $\mathbf{Z}$ represents a vector of firm-specific covariates that may affect insurer performance change, as shown in the literature. ${ }^{33}$ Our main coefficient of interest is the difference-in-differences estimate $\delta$. The estimate captures the difference in $\Delta P_{i, t}$ between abandoners and non-abandoners during the post-Spitzer period (after removing the time trend and controlling for the fundamental differences between the two groups).

Firm-specific factors included in the model that are hypothesised to affect firm performance change generally follow previous literature. ${ }^{34}$ Such variables include level of contingent commission usage (CONTINGENTRATIO), firm size (SIZE), financial stress level ( $L E V E R A G E)$, book-of-business mix (COMMERCIAL), product line diversification (PRODUCTHERF), geographical diversification (GEOHERF), distribution system (DIRECT), organisational structure (STOCK), and group affiliation $(U N A F F I L) .{ }^{35}$ The control variables in the regressions take $t-1$ values.

\footnotetext{
${ }^{32}$ For a deeper discussion of the application of the difference-in-difference estimation technique please see, for example, Card and Krueger (1994) and Abadie (2003).

${ }^{33}$ Cummins et al. (1999); He et al. (2011).

${ }^{34}$ Cummins et al. (1999); Cummins and Xie (2008); He et al. (2011).

35 These variables are included in the regressions as pure control variables, since the literature does not offer a clear-cut relationship of these variables to firm performance change. However, since rich literature has shown that these variables are to be related to firm performance level, it is likely that their current level is relevant to future changes in performance (He et al., 2011). As a result, they are controlled in the model as has been done in previous literature.
} 
Table 1 Summary statistics on firm performance change $(t-1, t+1)$ : Abandoners of contingent commissions vs. firms continuously using contingent commissions

\begin{tabular}{|c|c|c|c|c|c|c|c|}
\hline \multirow[t]{2}{*}{ Variables } & \multirow[t]{2}{*}{$\begin{array}{l}\text { Number of } \\
\text { firms }\end{array}$} & \multicolumn{2}{|c|}{ Abandoners } & \multirow[t]{2}{*}{$\begin{array}{l}\text { Number of } \\
\text { firms }\end{array}$} & \multicolumn{2}{|c|}{$\begin{array}{c}\text { Users throughout } \\
\text { 1993-2004 }\end{array}$} & \multirow[t]{2}{*}{$T$-tests } \\
\hline & & Mean & $\begin{array}{l}\text { Standard } \\
\text { deviation }\end{array}$ & & Mean & $\begin{array}{l}\text { Standard } \\
\text { deviation }\end{array}$ & \\
\hline $\mathrm{CE}$ & 229 & 1.201 & 0.587 & 2,849 & 1.109 & 0.322 & $0.092 * *$ \\
\hline RE & 229 & 1.073 & 0.641 & 2,849 & 0.991 & 0.444 & $0.082 *$ \\
\hline TFP & 229 & 1.103 & 0.529 & 2,849 & 1.008 & 0.123 & $0.094 * * *$ \\
\hline \multicolumn{8}{|c|}{ Panel B: Post-Spitzer investigation } \\
\hline \multirow[t]{2}{*}{ Variables } & \multirow[t]{2}{*}{$\begin{array}{l}\text { Number of } \\
\text { firms }\end{array}$} & \multicolumn{2}{|c|}{ Abandoners } & $\begin{array}{l}\text { Number of } \\
\text { firms }\end{array}$ & \multicolumn{2}{|c|}{$\begin{array}{c}\text { Users throughout } \\
2003-2008\end{array}$} & $T$-tests \\
\hline & & Mean & $\begin{array}{l}\text { Standard } \\
\text { deviation }\end{array}$ & & Mean & $\begin{array}{l}\text { Standard } \\
\text { deviation }\end{array}$ & \\
\hline $\mathrm{CE}$ & 119 & 1.008 & 0.211 & 1,901 & 0.967 & 0.196 & $0.040 * *$ \\
\hline RE & 119 & 1.205 & 0.747 & 1,901 & 1.268 & 0.582 & -0.063 \\
\hline TFP & 119 & 1.023 & 0.222 & 1,901 & 0.988 & 0.165 & $0.034 *$ \\
\hline
\end{tabular}

*Significant at the 10 per cent level. **Significant at the 5 per cent level. ***Significant at the 1 per cent level.

\section{Empirical results}

Table 1 compares insurers that switched from using contingent commissions to abandon that form of remuneration with insurers that consistently used contingent commissions. For both pre- and post-Spitzer periods, insurers that abandoned the contingent commission practice experienced a significant increase in their $C E$ as well as $T F P$, relative to firms that did not switch. However, the level of the performance gain experienced by insurers that abandoned the contingent commission practice during post-Spitzer period is smaller. In addition, insurers that abandoned contingent commissions prior to the Spitzer investigation also experience greater improvement in $\mathrm{RE}$, while those that abandoned the practice during the post-Spitzer period do not experience the same benefits. Definitions and summary statistics of control variables are presented in Table 2. We present the mean, median, and standard deviation separately for pre- and post-Spitzer sample periods.

Table 3 presents the difference-in-difference regression results. We estimate regressions that correct for potential heteroscedasticity and allow for clustering of the error terms at the company level. The coefficients associated with the abandonment of the use of contingent commissions $(A B A N D O N)$ were all found to be positively significant across various performance measures, which suggests that firms that abandoned contingent commissions sometime during 1994-2003 experience a performance gain in CE, RE, and TFP compared to firms that continued using contingent 
Yu-Luen Ma et al Contingent Commission Abandonment and Insurer Performance

Table 2 Summary statistics of independent variables

\begin{tabular}{|c|c|c|c|c|c|c|}
\hline \multirow[t]{2}{*}{ Variable description } & \multicolumn{3}{|c|}{ Pre-Spitzer investigation } & \multicolumn{3}{|c|}{ Post-Spitzer investigation } \\
\hline & Mean & Median & $\begin{array}{l}\text { Standard } \\
\text { deviation }\end{array}$ & Mean & Median & $\begin{array}{l}\text { Standard } \\
\text { deviation }\end{array}$ \\
\hline Firm size (natural log of total assets) & 18.833 & 18.785 & 1.839 & 18.915 & 18.893 & 1.753 \\
\hline Total liability/Policyholder surplus & 1.936 & 1.847 & 1.039 & 1.812 & 1.740 & 0.892 \\
\hline$\%$ of premiums in commercial lines & 0.532 & 0.526 & 0.305 & 0.543 & 0.551 & 0.344 \\
\hline Line of business Herfindahl & 0.302 & 0.231 & 0.179 & 0.331 & 0.259 & 0.225 \\
\hline Geographic Herfindahl & 0.462 & 0.357 & 0.359 & 0.502 & 0.425 & 0.365 \\
\hline Indicator for direct writers & 0.066 & 0.000 & 0.249 & 0.065 & 0.000 & 0.246 \\
\hline Indicator for stock companies & 0.651 & 1.000 & 0.477 & 0.703 & 1.000 & 0.457 \\
\hline Indicator for unaffiliated single firms & 0.216 & 0.000 & 0.412 & 0.216 & 0.000 & 0.411 \\
\hline Scale of contingent commission $(\%)$ & 12.005 & 8.830 & 14.000 & 14.205 & 11.540 & 14.785 \\
\hline
\end{tabular}

Table 3 Difference-in-difference regressions of changes in firm performance $(t-1, t+1)$

\begin{tabular}{|c|c|c|c|}
\hline Variables & $C E$ & $R E$ & $T F P$ \\
\hline POST & $\begin{array}{c}-0.1360 * * * \\
{[0.006]}\end{array}$ & $\begin{array}{l}0.2842^{* * * *} \\
{[0.015]}\end{array}$ & $\begin{array}{c}-0.0222 * * * \\
{[0.006]}\end{array}$ \\
\hline ABANDON & $\begin{array}{l}0.0804 * * \\
{[0.039]}\end{array}$ & $\begin{array}{l}0.0791^{*} \\
{[0.044]}\end{array}$ & $\begin{array}{l}0.0909 * * * \\
{[0.035]}\end{array}$ \\
\hline POST*ABANDON & $\begin{array}{c}-0.0632 \\
{[0.043]}\end{array}$ & $\begin{array}{c}-0.1525^{*} \\
{[0.081]}\end{array}$ & $\begin{array}{r}-0.0605 \\
{[0.041]}\end{array}$ \\
\hline CONTINGENTRATIO & $\begin{array}{c}-0.0012^{* * *} \\
{[0.000]}\end{array}$ & $\begin{array}{c}-0.0009 \\
{[0.001]}\end{array}$ & $\begin{array}{c}-0.0007 * * \\
{[0.000]}\end{array}$ \\
\hline SIZE & $\begin{array}{c}-0.0093 * * * \\
{[0.002]}\end{array}$ & $\begin{array}{c}-0.0220 * * * \\
{[0.005]}\end{array}$ & $\begin{array}{c}-0.0019 \\
{[0.002]}\end{array}$ \\
\hline LEVERAGE & $\begin{array}{l}0.0162 * * * \\
{[0.005]}\end{array}$ & $\begin{array}{l}0.0187 * * \\
{[0.009]}\end{array}$ & $\begin{array}{c}-0.0195^{* * *} * \\
{[0.004]}\end{array}$ \\
\hline COMMERCIAL & $\begin{array}{c}-0.0777 * * * \\
{[0.011]}\end{array}$ & $\begin{array}{c}-0.0763 * * * \\
{[0.023]}\end{array}$ & $\begin{array}{r}0.0087 \\
{[0.010]}\end{array}$ \\
\hline PRODUCTHERF & $\begin{array}{l}0.0614 * * * \\
{[0.023]}\end{array}$ & $\begin{array}{c}-0.0312 \\
{[0.045]}\end{array}$ & $\begin{array}{c}0.0098 \\
{[0.023]}\end{array}$ \\
\hline GEOHERF & $\begin{array}{c}0.0161 \\
{[0.014]}\end{array}$ & $\begin{array}{c}-0.0176 \\
{[0.024]}\end{array}$ & $\begin{array}{c}-0.0028 \\
{[0.012]}\end{array}$ \\
\hline DIRECT & $\begin{array}{c}0.0075 \\
{[0.017]}\end{array}$ & $\begin{array}{c}0.0289 \\
{[0.032]}\end{array}$ & $\begin{array}{c}-0.0053 \\
{[0.016]}\end{array}$ \\
\hline STOCK & $\begin{array}{c}-0.008 \\
{[0.007]}\end{array}$ & $\begin{array}{c}0.0184 \\
{[0.014]}\end{array}$ & $\begin{array}{l}0.0156^{* *} \\
{[0.007]}\end{array}$ \\
\hline UNAFFIL & $\begin{array}{c}-0.0035 \\
{[0.011]}\end{array}$ & $\begin{array}{c}-0.0352^{*} \\
{[0.020]}\end{array}$ & $\begin{array}{c}-0.0098 \\
{[0.009]}\end{array}$ \\
\hline Constant & $\begin{array}{l}1.2884 * * * \\
{[0.052]}\end{array}$ & $\begin{array}{l}1.4322 * * * \\
{[0.100]}\end{array}$ & $\begin{array}{l}1.0761 * * * \\
{[0.045]}\end{array}$ \\
\hline Observations & 5,097 & 5,097 & 5,097 \\
\hline Adj $R$-squared & 0.073 & 0.065 & 0.027 \\
\hline
\end{tabular}

*Significant at the 10 per cent level. **Significant at the 5 per cent level. ***Significant at the 1 per cent level. Standard errors in brackets. 
commissions. These findings support Hypothesis 1, as we expect the decision to abandon the use of contingent commissions to have been made for strategic reasons designed to support the overall performance of the company. The coefficients for the interaction term of the post-Spitzer period and the abandoners $\left(P O S T^{*} A B A N D O N\right)$ reveal the changes in firm performance for abandoners during the post-Spitzer period. Without exception, the coefficients for this variable are negative across all models, although only statistically significant at the 10 per cent level for $R E$. These results suggest that abandoners do not experience comparable gains in performance during the post-Spitzer period compared to the gains experienced during the pre-Spitzer period. The negative significance identified in the $R E$ model indicates that abandoning contingent commissions during the post-Spitzer may even be associated with a reduction in RE. Our findings provide partial support for Hypothesis 2, which predicts performance losses (negative significance) associated with the decision to abandon the use of contingent commissions. One possible explanation for these results is a dilution effect. Certainly, in the negatively charged post-Spitzer environment, the decision to abandon the use of contingent commissions by some insurers may be motivated primarily to protect their reputation and thus result in a reduction in the level of their performance. ${ }^{36}$ However, some insurers may have abandoned the practice for traditional performancebased reasons. As a result, the overall net effect is a dilution of the positive statistical relationship found in the pre-Spitzer period.

Another interesting finding is that the coefficients for the post-Spitzer period (POST) are negatively significant for $C E$ and $T F P$, but positively significant for $R E$. These results indicate insurers that had been continuously using contingent commissions experienced a reduction in CE and TFP, but gained in RE during the post-Spitzer period. Combined with the general insignificance associated with the interaction term, our results suggest that the abandoners experienced similar amounts of reduction in CE and TFP as non-abandoners during the post-Spitzer period. In addition, they did not experience as much gain in RE as did insurers that continued to use contingent commissions.

To examine the robustness of our results, we perform several alternative analyses. We redefined abandoners as those who have been using contingent commissions throughout the years until the abandonment year, and never returning to its use during the time span for which we have data. Under this alternative definition, 22 and 39 insurers with efficiency change estimation available are classified as abandoners for the pre- and post-Spitzer periods, respectively. The results of the alternative analysis are reported in Table 4 . As can be seen, the coefficients for abandonment $(A B A N D O N)$ are positively significant and the coefficients for the interaction term controlling for abandonment during the post-Spitzer period $\left(P O S T^{*} A B A N D O N\right)$ are negatively significant for all models. The results from these alternative models are stronger and possess greater statistical significance compared to our main analysis, due to the more restrictive definition of abandoners. When taken together, the results from these alterative models support both Hypotheses 1 and 2 and also support the contention that the abandonment of

\footnotetext{
${ }^{36}$ As predicted by Ghosh and Hilliard (2012).
} 
Table 4 Difference-in-difference regressions of changes in firm performance $(t-1, t+1)$ where abandoners never switch back

\begin{tabular}{|c|c|c|c|}
\hline Variables & $C E$ & $R E$ & $T F P$ \\
\hline POST & $\begin{array}{c}-0.1366^{* * *} \\
{[0.006]}\end{array}$ & $\begin{array}{l}0.2845^{* * *} \\
{[0.015]}\end{array}$ & $\begin{array}{c}-0.0220 * * * \\
{[0.006]}\end{array}$ \\
\hline ABANDON & $\begin{array}{l}0.3853^{* *} \\
{[0.170]}\end{array}$ & $\begin{array}{l}0.4441^{* *} \\
{[0.207]}\end{array}$ & $\begin{array}{l}0.4691^{* *} \\
{[0.200]}\end{array}$ \\
\hline POST*ABANDON & $\begin{array}{c}-0.4182^{* *} \\
{[0.173]}\end{array}$ & $\begin{array}{c}-0.5653^{* *} \\
{[0.229]}\end{array}$ & $\begin{array}{c}-0.4704^{* *} \\
{[0.201]}\end{array}$ \\
\hline CONTINGENTRATIO & $\begin{array}{c}-0.0010^{* *} \\
{[0.000]}\end{array}$ & $\begin{array}{c}-0.001 \\
{[0.001]}\end{array}$ & $\begin{array}{c}-0.0006^{*} \\
{[0.000]}\end{array}$ \\
\hline SIZE & $\begin{array}{c}-0.0072^{* * *} \\
{[0.002]}\end{array}$ & $\begin{array}{c}-0.0182^{* * * *} \\
{[0.005]}\end{array}$ & $\begin{array}{c}0.0001 \\
{[0.002]}\end{array}$ \\
\hline LEVERAGE & $\begin{array}{l}0.0171^{* * *} \\
{[0.004]}\end{array}$ & $\begin{array}{l}0.0231 * * * \\
{[0.009]}\end{array}$ & $\begin{array}{c}-0.0166^{* * *} \\
{[0.003]}\end{array}$ \\
\hline COMMERCIAL & $\begin{array}{c}-0.0738^{* * *} \\
{[0.011]}\end{array}$ & $\begin{array}{c}-0.0814^{* * * *} \\
{[0.023]}\end{array}$ & $\begin{array}{c}0.0089 \\
{[0.010]}\end{array}$ \\
\hline PRODUCTHERF & $\begin{array}{l}0.0650^{* * *} \\
{[0.023]}\end{array}$ & $\begin{array}{c}0.0183 \\
{[0.046]}\end{array}$ & $\begin{array}{c}0.0074 \\
{[0.021]}\end{array}$ \\
\hline GEOHERF & $\begin{array}{l}0.0197 * \\
{[0.012]}\end{array}$ & $\begin{array}{c}-0.0228 \\
{[0.023]}\end{array}$ & $\begin{array}{c}0.0019 \\
{[0.010]}\end{array}$ \\
\hline DIRECT & $\begin{array}{r}0.0106 \\
{[0.017]}\end{array}$ & $\begin{array}{r}0.0031 \\
{[0.029]}\end{array}$ & $\begin{array}{r}-0.0141 \\
{[0.011]}\end{array}$ \\
\hline STOCK & $\begin{array}{r}-0.0087 \\
{[0.007]}\end{array}$ & $\begin{array}{c}0.0104 \\
{[0.014]}\end{array}$ & $\begin{array}{l}0.0117^{* *} \\
{[0.006]}\end{array}$ \\
\hline UNAFFIL & $\begin{array}{c}0.0071 \\
{[0.011]}\end{array}$ & $\begin{array}{c}-0.0378^{*} \\
{[0.020]}\end{array}$ & $\begin{array}{c}-0.0076 \\
{[0.007]}\end{array}$ \\
\hline Constant & $\begin{array}{l}1.2382 * * * \\
{[0.042]}\end{array}$ & $\begin{array}{l}1.3505^{* * *} \\
{[0.093]}\end{array}$ & $\begin{array}{l}1.0327 * * * \\
{[0.037]}\end{array}$ \\
\hline $\begin{array}{l}\text { Observations } \\
\text { Adj } R \text {-squared }\end{array}$ & $\begin{array}{l}4,811 \\
0.083\end{array}$ & $\begin{array}{c}4,811 \\
0.071\end{array}$ & $\begin{array}{l}4,811 \\
0.053\end{array}$ \\
\hline
\end{tabular}

*Significant at the 10 per cent level. **Significant at the 5 per cent level. ***Significant at the 1 per cent level. Standard errors in brackets.

contingent commissions prior to the Spitzer investigation is more acutely associated with performance enhancement strategies, whereas abandonment during the postSpitzer period may be based on reasons that extend beyond mere performance.

We also re-estimated our original models using a fixed-effects methodology by including insurer-specific intercepts (results reported in Table 5). The results from fixed-effects models are very similar to those reported in Table 3, assuring that our conclusions remain the same when firm dummies are also included in the models. ${ }^{37}$

\footnotetext{
${ }^{37}$ We also perform a random effects analysis as an additional robustness check whose results parallel those of the OLS analysis presented in the paper. However, given that the Hausman test favours the use of a fixed effects analysis, we include those results in the paper and do not report the results of the random effects analysis.
} 
Table 5 Difference-in-difference regressions of changes in firm performance $(t-1, t+1)$ : Fixed effects models

\begin{tabular}{|c|c|c|c|}
\hline Variables & $C E$ & $R E$ & $T F P$ \\
\hline POST & $\begin{array}{l}-0.0444 * * * \\
{[0.014]}\end{array}$ & $\begin{array}{l}0.5478 * * * \\
{[0.027]}\end{array}$ & $\begin{array}{c}-0.0361 * * * \\
{[0.006]}\end{array}$ \\
\hline ABANDON & $\begin{array}{l}0.1915^{* * *} \\
{[0.069]}\end{array}$ & $\begin{array}{c}0.0978 \\
{[0.104]}\end{array}$ & $\begin{array}{c}0.0650^{*} \\
{[0.033]}\end{array}$ \\
\hline POST*ABANDON & $\begin{array}{c}-0.0067 \\
{[0.065]}\end{array}$ & $\begin{array}{c}-0.1932^{*} \\
{[0.107]}\end{array}$ & $\begin{array}{r}0.0251 \\
{[0.045]}\end{array}$ \\
\hline CONTINGENTRATIO & $\begin{array}{c}-0.0018^{* *} \\
{[0.001]}\end{array}$ & $\begin{array}{c}-0.0001 \\
{[0.001]}\end{array}$ & $\begin{array}{r}-0.0001 \\
{[0.000]}\end{array}$ \\
\hline SIZE & $\begin{array}{c}-0.1665^{* * *} \\
{[0.027]}\end{array}$ & $\begin{array}{c}-0.5162^{* * * *} \\
{[0.039]}\end{array}$ & $\begin{array}{c}-0.0006 \\
{[0.010]}\end{array}$ \\
\hline LEVERAGE & $\begin{array}{l}0.0324 * * * \\
{[0.011]}\end{array}$ & $\begin{array}{l}0.0650 * * * \\
{[0.019]}\end{array}$ & $\begin{array}{c}-0.0295 * * * \\
{[0.005]}\end{array}$ \\
\hline COMMERCIAL & $\begin{array}{l}0.2955^{* * *} \\
{[0.086]}\end{array}$ & $\begin{array}{c}-0.045 \\
{[0.144]}\end{array}$ & $\begin{array}{l}0.2086^{* * * *} \\
{[0.048]}\end{array}$ \\
\hline PRODUCTHERF & $\begin{array}{l}0.2918 * * \\
{[0.116]}\end{array}$ & $\begin{array}{c}0.0039 \\
{[0.202]}\end{array}$ & $\begin{array}{c}0.0464 \\
{[0.056]}\end{array}$ \\
\hline GEOHERF & $\begin{array}{l}0.1697 * * \\
{[0.069]}\end{array}$ & $\begin{array}{c}0.0099 \\
{[0.098]}\end{array}$ & $\begin{array}{c}-0.0941 * * * \\
{[0.024]}\end{array}$ \\
\hline DIRECT & $\begin{array}{c}0.0258 \\
{[0.084]}\end{array}$ & $\begin{array}{c}0.1879 \\
{[0.123]}\end{array}$ & $\begin{array}{c}0.0171 \\
{[0.028]}\end{array}$ \\
\hline STOCK & $\begin{array}{r}-0.0765 \\
{[0.092]}\end{array}$ & $\begin{array}{c}-0.1718 \\
{[0.105]}\end{array}$ & $\begin{array}{c}-0.0195 \\
{[0.024]}\end{array}$ \\
\hline UNAFFIL & $\begin{array}{c}0.065 \\
{[0.047]}\end{array}$ & $\begin{array}{c}0.0081 \\
{[0.067]}\end{array}$ & $\begin{array}{c}-0.0173 \\
{[0.014]}\end{array}$ \\
\hline Constant & $\begin{array}{l}2.2415^{* * *} \\
{[0.437]}\end{array}$ & $\begin{array}{l}7.9720 * * * \\
{[0.674]}\end{array}$ & $\begin{array}{l}0.7262 * * * \\
{[0.179]}\end{array}$ \\
\hline $\begin{array}{l}\text { Observations } \\
\text { Adj } R \text {-squared }\end{array}$ & $\begin{array}{l}5,097 \\
0.181\end{array}$ & $\begin{array}{l}5,097 \\
0.169\end{array}$ & $\begin{array}{l}5,097 \\
0.501\end{array}$ \\
\hline
\end{tabular}

*Significant at the 10 per cent level. **Significant at the 5 per cent level. ***Significant at the 1 per cent level.

Firm dummy variables are included in the models, but are not reported here. Standard errors in brackets.

\section{Conclusion}

The research examines the relationship between an insurer's decision to abandon the use of contingent commissions and that decision's effect on firm performance. We employ difference-in-difference regression models that assess the relationship across two periods - before and after the initiation of the landmark Spitzer investigation in 2004. We hypothesise that the use of contingent commissions represents a threat to an insurer's reputation in the post-Spitzer period and as such, presents a new motivation for the abandonment of the use of that practice, a motivation not present prior to 2004. Our findings support our hypotheses that motivations for the abandonment of the use of contingent commissions prior to the Spitzer investigation were rewarded with relatively higher performance results. In addition, those who abandoned the 
practice subsequent to the initiation of the Spitzer investigation did not experience similar rewards in terms of performance. We attribute these results to the efforts of insurers to distance themselves from the negative publicity associated with the practice of contingent commissions as a form of intermediary remuneration, that is, the cost of reputation preservation. This paper represents one of the first forays into an assessment of the reputational risk associated with the use of contingent commissions in the U.S. property-casualty insurance marketplace. Given the theorised benefits of the use of contingent commissions, the decision to abandon contingent commissions to protect one's reputation is found to be reflected in a decrease in performance.

\section{References}

Abadie, A. (2003) 'Semiparametric Difference-in-differences Estimators', Harvard University and NBER, from http://athens.src.uchicago.edu/jenni/econ350/Abadie2003.pdf, accessed 30 September 2012.

Berger, A.N., Cummins, J.D. and Weiss, M.A. (1997) 'The coexistence of multiple distribution systems for financial services: The case of property-liability insurance', The Journal of Business 70(4): 515-546.

Berger, A.N. and Humphrey, D.B. (1997) 'Efficiency of financial institutions: International survey and directions for future research', European Journal of Operational Research 98(2): 175-212.

Card, D. and Krueger, A. (1994) 'Minimum wages and employment: A case study of the fast-food industry in New Jersey and Pennsylvania', American Economic Review 184(4): 772-793.

Cheng, J., Elyasiani, E. and Lin, T.T. (2010) 'Market reaction to regulatory action in the insurance industry: The case of contingent commission', The Journal of Risk and Insurance 77(2): 347-368.

Colquitt, L.L., McCullough, K.A. and Sommer, D.W. (2011) 'An analysis of contingent commission use by property-liability insurers', Risk Management and Insurance Review 14(2): 157-171.

Cooper, W.W., Seiford, L.M. and Tone, K. (2000) Data envelopment analysis, Norwell, MA: Kluwer Academic Publishers.

Csiszar, E. and Heidrich, G.W. (2006) 'The question of reputational risk: Perspectives from an industry', The Geneva Papers on Risk and Insurance - Issues and Practice 31(3): 382-394.

Cummins, J.D. and Doherty, N. (2006) 'The economics of insurance intermediaries', The Journal of Risk and Insurance 73(3): 359-396.

Cummins, J.D. and Nini, G. (2002) 'Optimal capital utilization by financial firms: Evidence from the property-liability insurance industry', Journal of Financial Services Research 21(1-2): 15-53.

Cummins, J.D. and Phillips, R.D. (2005) 'Estimating the cost of equity capital for property-liability insurers', The Journal of Risk and Insurance 72(3): 441-478.

Cummins, J.D., Tennyson, S. and Weiss, M.A. (1999) 'Consolidation and efficiency in the US life insurance industry', Journal of Banking \& Finance 23(2-4): 325-357.

Cummins, J.D. and Weiss, M.A. (2011) 'Analyzing firm performance in the insurance industry using frontier efficiency and productivity methods', in G. Dionne (ed.) Handbook of Insurance, 2nd edn, Boston, MA: Kluwer Academic Publishers.

Cummins, J.D. and Xie, X. (2008) 'Mergers and acquisitions in the US property-liability insurance industry: Productivity and efficiency effects', Journal of Banking \& Finance 32(1): 30-55.

Fare, R., Grosskopf, S., Norris, M. and Zhang, Z. (1994) 'Productivity growth, technical progress and efficiency change in the industrialized countries', American Economic Review 84(1): 66-83.

Fitzpatrick, S. (2006) 'The small laws: Eliot Spitzer and the way to insurance market reform', Fordham Law Review 74(6): 3041-3071.

Ghosh, C. and Hilliard, J. (2012) 'The value of contingent commissions in the property-casualty insurance industry: Evidence from stock market returns', The Journal of Risk and Insurance 79(1): 165-191.

Grosskopf, S. (1993) 'Efficiency and productivity', in H.O. Fried, C.A.K. Lovell and S.S. Schmidt (eds.) The Measurement of Productive Efficiency: Techniques and Application, New York: Oxford University Press.

Hartwig, R. (2005) 'Analysis of the Consumer Federation of America Report on Contingent Commissions', from http://www.iii.org/, accessed 1 February 2007. 
He, E., Sommer, D.W. and Xie, X. (2011) 'The impact of CEO turnover on property-liability insurer performance', The Journal of Risk and Insurance 78(3): 583-608.

Hoyt, R., Dumm, R. and Carson, J. (2006) An examination of the role of insurance producers and compensation in the insurance industry, white paper, Florida State University.

$\mathrm{Ju}, \mathrm{L}$. and Tu, Z. (2011) Buffering effect of insurance intermediaries: Does the use of contingent commissions dampen the insurance underwriting cycle? unpublished working paper, from http://www.wu.ac.at/ egrie2011/programme/papers/vii.b2.ju.pdf.

Ma, Y., Pope, N. and Xie, X. (2009) 'Insurer performance and contingent commissions: What's the relationship?' Journal of Financial and Economic Practice 9(2): 45-57.

Ma, Y., Pope, N. and Xie, X. (2013) 'Contingent commissions, insurance intermediaries and insurer efficiency', Risk Management and Insurance Review, forthcoming.

Regan, L. and Kleffner, A. (2010) The role of contingent commissions in property-liability insurer underwriting performance, paper presented at the 2010 Risk Theory Society Meeting, Athens, GA.

Schwarcz, D.B. (2007) 'Beyond disclosure: The case for banning contingent commissions', Yale Law \& Public Policy Review 25(2): 289-336.

Simpson, A.G. (2010) 'Marsh Joins Aon, Willis in Rejecting Contingent Commission Income', Insurance Journal, from http://www.insurancejournal.com/news/national/2010/03/25/108446.htm, accessed 19 June 2012.

Wade, R. (2005) 'A Brief History of Contingent Commission Agreements', from http://www.kpmginsiders .com, accessed 1 February 2007. 